\title{
Steel Corrosion Induced by Chloride or Carbonation in Mortar with Bending Cracks or Joints
}

\author{
Shin-ichi Miyazato ${ }^{1}$ and Nobuaki Otsuki ${ }^{2}$
}

Received 19 January 2010, accepted 29 April 2010

\begin{abstract}
Steel in concrete may corrode due to chloride or carbonation especially at cracks and joints. The objective of this study is to experimentally investigate comprehensively the pattern of corrosion cell formation (macrocell and microcell) as well as the corrosion rate using mortar specimens with defects simulating cracks and/or joints. The three important factors are listed as follows: 1) supply position of chloride ions or carbon dioxide, 2) environmental conditions, and 3) water-cement ratio of mortar. The results indicate that, in the case of chloride induced corrosion, decreasing the water-cement ratio (0.3) increased the activity of macrocell prominent corrosion. On the other hand, increasing the water-cement ratio (0.7) increased the activity of microcell prominent corrosion. Therefore, in the presence of defects, a high corrosion rate might be promoted even at a low water-cement ratio. The study also reveals that, in the case of carbonation induced corrosion, macrocell prominent corrosion occurred regardless of the water-cement ratio, and the lower the water-cement ratio, the lower the corrosion rate. Finally, the study proves that the corrosion rate induced by chloride was higher than that induced by carbonation.
\end{abstract}

\section{Introduction}

The reinforcement in concrete is in a high alkali environment. Therefore, a passive film forms around the reinforcement and protects the reinforcement from corrosion. However, chloride ingress and carbonation induce the corrosion of the reinforcement in concrete. Corrosion is especially worse when chloride ions, carbon dioxide, water and oxygen invade defects such as cold joints and bending cracks. Also, it is assumed that the corrosive state changes based on the type of defects, external environment and water-cement ratio of concrete. Therefore, it is necessary to examine and arrange in detail whether the corrosion cell formation pattern is mainly macrocell or microcell and determine the rate of corrosion.

Many research papers discuss the influence of chloride ions on the corrosion of reinforcement in concrete (Beeby 1983; Andrade et al. 1992; Schiebl and Raupach1997; Otsuki et al. 2009) where some papers dealt with the macrocell corrosion (Ominda and Kato 2009). However, no research has comprehensively examined and compared the influences of the defect type, external environment, and quality of concrete.

Against the above background, this study was conducted to determine the pattern of corrosion cell formation (macrocell corrosion or microcell corrosion) and

\footnotetext{
${ }^{1}$ Associate Professor, Kanazawa Institute of Technology, Hakusan, Ishikawa Prefecture, Japan.

E-mail:miyazato@neptune.kanazawa-it.ac.jp

${ }^{2}$ Professor, Department of International Department Engineering, Tokyo Institute of Technology, Tokyo, Japan.
}

the rate of corrosion, which was induced by chloride and carbonation in a reinforced concrete member with defects such as bending cracks and/or joints.

\section{Experimental procedure}

\subsection{Materials}

The materials include ordinary Portland cement, sand, chemical admixtures and round steel bars $9 \mathrm{~mm}$ in diameter. The basic characteristics of the materials are listed in Table 1. The chemical composition of the steel is shown in Table 2.

\subsection{Experiment cases}

The experiment cases are listed in Table 3.

Three methods of supplying chloride ions to the steel bar were used: 1) spraying a $6 \mathrm{ml} \mathrm{NaCl}$ solution $(3.5 \%$ by weight) at the joint once every 3.5 days (no chloride ions when mixing); 2) pouring $6 \mathrm{ml}$ of $\mathrm{NaCl}$ solution (3.5\% by weight) at and around the joint once every 3.5 days (no chloride ions when mixing); and 3) incorporation of $15.0 \mathrm{~kg} / \mathrm{m}^{3}$ chloride ion during mortar mixing (entire specimen). In addition, there were three types of environmental conditions: wet, dry and repetition of wet and dry cycles. The wet environment was $90 \% \mathrm{RH}$ and 20 degrees Celsius. The dry environment was $50 \% \mathrm{RH}$ and 20 degrees Celsius. The repetition environment was achieved by exposing the specimen to a cyclic wet period of 24 hours followed by a 60 hour dry period. The water-cement ratio of mortar was varied between 0.3 , 0.5 and 0.7 . A total of 27 cases were used for the chloride induced corrosion.

On the other hand, three methods of supplying carbon dioxide to the steel bar were used: 1) introducing carbon dioxide gas at the joint only; 2) introducing carbon di- 
oxide gas at and near the joint; and 3) introducing carbon dioxide gas to the whole specimen. There were also three types of environmental conditions and three levels of water-cement ratios used in the chloride induced corrosion, for a total of 27 cases for carbonation induced corrosion.

\subsection{Preparation of specimens}

The specimen configuration is shown in Fig. 1. The

Table 1 Materials used.

\begin{tabular}{|c|c|c|}
\hline & Type & Characteristics \\
\hline Cement & $\begin{array}{l}\text { Ordinary Port- } \\
\text { land cement }\end{array}$ & $\begin{array}{l}\text { Density }=3.15 \mathrm{~g} / \mathrm{cm}^{3}, \\
\text { Specific surface }=3.27 \mathrm{~m}^{2} / \mathrm{kg}\end{array}$ \\
\hline $\begin{array}{c}\text { Fine } \\
\text { aggregate }\end{array}$ & Land sand & $\begin{array}{l}\text { Density }=2.60 \mathrm{~g} / \mathrm{cm}^{3}, \\
\text { Fineness modulus }=2.59 \\
\text { Water absorption }=2.20 \%\end{array}$ \\
\hline \multirow{2}{*}{$\begin{array}{l}\text { Chemical } \\
\text { admixture }\end{array}$} & Superplasticizer & $\begin{array}{l}\text { Naphthalenesulfonic } \\
\text { acid type }\end{array}$ \\
\hline & $\begin{array}{l}\text { High viscosity } \\
\text { agent }\end{array}$ & Methyl cellulose type \\
\hline Steel & Round bar & Yield strength $=354 \mathrm{~N} / \mathrm{mm}^{2}$ \\
\hline
\end{tabular}

Table 2 Chemical composition of steel (\%).

\begin{tabular}{|c|c|c|c|c|c|}
\hline $\mathrm{Fe}$ & $\mathrm{C}$ & $\mathrm{Si}$ & $\mathrm{Mn}$ & $\mathrm{P}$ & $\mathrm{S}$ \\
\hline 99.13 & 0.12 & 0.12 & 0.58 & 0.031 & 0.023 \\
\hline
\end{tabular}

reinforcement was composed of nine element bars for the purpose of measuring macrocell corrosion currents. Two 30-mm long bars, two 20-mm long bars, two $10-\mathrm{mm}$ long bars, and three $5-\mathrm{mm}$ long bars were used for each specimen. Lead wires were soldered at both ends of the segments before these segments were joined with epoxy resin of high insulating capacity to form a 159-mm long reinforcement. The steel was divided into small segments to examine in detail corrosion near the defect.

A joint was fabricated through 2 steps as shown below. First, for specimens Nos. 10 to 18 and Nos. 37 to 45 , a normal filter was wrapped around the steel reinforcement covering the $21-\mathrm{mm}$ length near the joint. This represents a gap between the steel bar and concrete near the crack (Kamiyama 1972). After the steel bar was placed at the center of the mold, mortar was placed, filling in one half of the mold (left-side mortar in (1), (2), and (3) in Fig. 1). Next, one day after casting, mortar with the same mixture proportion was placed to completely fill up the mold (right-side mortar in (1), (2), and (3) in Fig. 1). This created a joint between the separately cast mortars. For specimens Nos. 1 to 18 and Nos. 28 to 45 , a normal filter of $0.5 \mathrm{~mm}$ width was inserted into the joint prior to placing of the right-side-mortar. Both the left-side and right-side mortars for specimens Nos. 19 to 27 contained $15.0 \mathrm{~kg} / \mathrm{m}^{3}$ chloride ion.

Table 3 Experiment cases.

\begin{tabular}{|c|c|c|c|c|c|c|c|}
\hline No. & Supply of $\mathrm{Cl}^{-}$ & Environment & $\mathrm{W} / \mathrm{C}$ & No. & Supply of $\mathrm{CO}_{2}$ & Environment & $\mathrm{W} / \mathrm{C}$ \\
\hline 1 & \multirow{9}{*}{ Joint only } & \multirow{3}{*}{ Wet } & 0.3 & 28 & \multirow{9}{*}{ Joint only } & \multirow{3}{*}{ Wet } & 0.3 \\
\hline 2 & & & 0.5 & 29 & & & 0.5 \\
\hline 3 & & & 0.7 & 30 & & & 0.7 \\
\hline 4 & & Dru ond wet & 0.3 & 31 & & \multirow{3}{*}{$\begin{array}{l}\text { Dry and wet repe- } \\
\text { tition }\end{array}$} & 0.3 \\
\hline 5 & & renetition & 0.5 & 32 & & & 0.5 \\
\hline 6 & & & 0.7 & 33 & & & 0.7 \\
\hline 7 & & \multirow{3}{*}{ Dry } & 0.3 & 34 & & \multirow{3}{*}{ Dry } & 0.3 \\
\hline 8 & & & 0.5 & 35 & & & 0.5 \\
\hline 9 & & & 0.7 & 36 & & & 0.7 \\
\hline 10 & \multirow{9}{*}{$\begin{array}{l}\text { Joint and its sur- } \\
\text { roundings }\end{array}$} & \multirow{3}{*}{ Wet } & 0.3 & 37 & \multirow{9}{*}{$\begin{array}{l}\text { Joint and its } \\
\text { surroundings }\end{array}$} & \multirow{3}{*}{ Wet } & 0.3 \\
\hline 11 & & & 0.5 & 38 & & & 0.5 \\
\hline 12 & & & 0.7 & 39 & & & 0.7 \\
\hline 13 & & \multirow{3}{*}{$\begin{array}{l}\text { Dry and wet } \\
\text { repetition }\end{array}$} & 0.3 & 40 & & \multirow{3}{*}{$\begin{array}{l}\text { Dry and wet repe- } \\
\text { tition }\end{array}$} & 0.3 \\
\hline 14 & & & 0.5 & 41 & & & 0.5 \\
\hline 15 & & & 0.7 & 42 & & & 0.7 \\
\hline 16 & & \multirow{3}{*}{ Dry } & 0.3 & 43 & & \multirow{3}{*}{ Dry } & 0.3 \\
\hline 17 & & & 0.5 & 44 & & & 0.5 \\
\hline 18 & & & 0.7 & 45 & & & 0.7 \\
\hline 19 & \multirow{9}{*}{ Whole part } & \multirow{3}{*}{ Wet } & 0.3 & 46 & \multirow{9}{*}{ Whole part } & \multirow{3}{*}{ Wet } & 0.3 \\
\hline 20 & & & 0.5 & 47 & & & 0.5 \\
\hline 21 & & & 0.7 & 48 & & & 0.7 \\
\hline 22 & & \multirow{3}{*}{$\begin{array}{l}\text { Dry and wet } \\
\text { repetition }\end{array}$} & 0.3 & 49 & & \multirow{3}{*}{$\begin{array}{l}\text { Dry and wet repe- } \\
\text { tition }\end{array}$} & 0.3 \\
\hline 23 & & & 0.5 & 50 & & & 0.5 \\
\hline 24 & & & 0.7 & 51 & & & 0.7 \\
\hline 25 & & \multirow{3}{*}{ Dry } & 0.3 & 52 & & \multirow{3}{*}{ Dry } & 0.3 \\
\hline 26 & & & 0.5 & 53 & & & 0.5 \\
\hline 27 & & & 0.7 & 54 & & & 0.7 \\
\hline
\end{tabular}




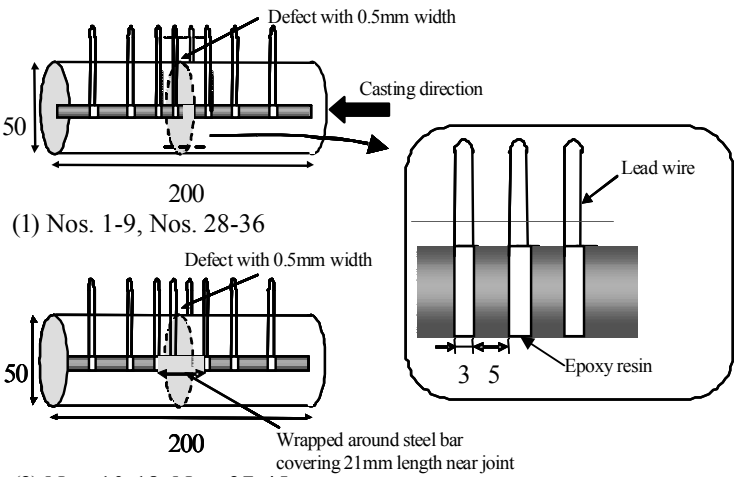

(2) Nos. 10-18, Nos. 37-45

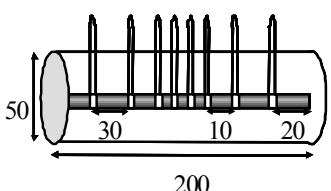

(3) Nos. $19-27$, Nos. $46-54$

Fig. 1 Specimen and steel reinforcement.

Table 4 Mixture proportion and fresh characteristics of mortar.

\begin{tabular}{|c|c|c|c|c|c|}
\hline \multirow[b]{2}{*}{$\mathrm{W} / \mathrm{C}$} & \multirow[b]{2}{*}{$\mathrm{S} / \mathrm{C}$} & \multicolumn{2}{|c|}{$\begin{array}{c}\text { Chemical admixture } \\
\left(\text { Cement } *_{\mathrm{wt}} \%\right)\end{array}$} & \multirow{2}{*}{$\begin{array}{l}\text { Slump } \\
\text { flow }\end{array}$} & \multirow{2}{*}{$\begin{array}{l}\text { Bleeding } \\
\quad(\%)\end{array}$} \\
\hline & & Superplasticizer & $\begin{array}{c}\text { High } \\
\text { viscosity } \\
\text { agent }\end{array}$ & & \\
\hline 0.3 & \multirow{3}{*}{2.5} & 2.0 & - & 170 & 0.1 \\
\hline 0.5 & & - & - & 200 & 0.3 \\
\hline 0.7 & & - & 1.2 & 260 & 0.4 \\
\hline
\end{tabular}

The mixture proportion of the mortar is shown in Table $4 . \mathrm{S} / \mathrm{C}$ is 2.5 . In addition, a superplasticizer was used for the mortar of 0.3 water-cement ratio to prevent segregation, while a high viscosity agent was used for the mortar of 0.7 water-cement ratio.

\subsection{Exposure conditions}

All specimens were subjected to initial curing in a wet environment for 27 days following removal from the mold.

Then, specimens Nos. 1 to 27, used to test chloride induced corrosion, were exposed for 56 days to the various environmental conditions (wet, dry, dry and wet repetition), as detailed in Table 3.

Specimens Nos. 28 to 54, used to test carbonation induced corrosion, were exposed for 56 days to a $10 \%$ $\mathrm{CO}_{2}$ concentration, 40 degrees Celsius and $70 \% \mathrm{RH}$, after initial curing. Carbonation of the mortar was checked during this exposure period, by splitting spare specimens of 9 kinds (3 types of specimens, 3 levels of water-cement ratio) made under similar conditions, and spraying them with a phenolphthalein alcoholate. After the mortar in the vicinity of the steel bar was carbonated in each position shown in Table 3, exposure of the specimens to the carbonation promoting environment and the various environmental conditions (wet, dry, dry and wet repetition) was ceased.

\subsection{Measurement methods}

In this paper, macrocell corrosion current refers to the current flowing in a cell composed of all steel components, while microcell corrosion current refers to the current flowing in a cell when only one steel component is involved.

The corrosion cell formation pattern in the experiment using the special divided steel bar is shown in Fig. 2. There are two patterns if steel element No. 2 becomes an anode. One is the macrocell pattern, where other steel elements, No. 1, 3 and 4, become cathodes, as shown in Fig. 2 (1), and the other is the microcell pattern, where steel element No. 2 itself becomes a cathode, as shown in Fig. 2 (2). Thus, the total corrosion rate can be evaluated, if both macrocell and microcell corrosion currents are measured, in the case when steel element No. 2 becomes an anode.

1) Macrocell corrosion current

The macrocell corrosion current is the total electric current flowing through all steel components taken as a unit. This current was measured every 3.5 days using no-resistance ammeters. The current density was determined by dividing the total electric current by the surface area. For example, the macrocell corrosion current density of steel elements is shown in Fig. 3 is given by Eq. (1). The anode current density is presented as positive, while the cathode current density is presented as negative.

$$
a_{i}=\frac{I_{t-1,4}-I_{t, i+1}}{S_{i}}
$$

where $\mathrm{a}_{\mathrm{i}}=$ macrocell corrosion current density of steel component $i\left(\mathrm{~A} / \mathrm{cm}^{2}\right), I_{\mathrm{i}, \mathrm{j}}=$ macrocell corrosion current from steel components $i$ to $j(\mathrm{~A})$, and $\mathrm{S}_{\mathrm{i}}=$ surface area of steel element $i$.

If a corrosion current density of $100 \mathrm{micro} \mathrm{A} / \mathrm{cm}^{2}$ is

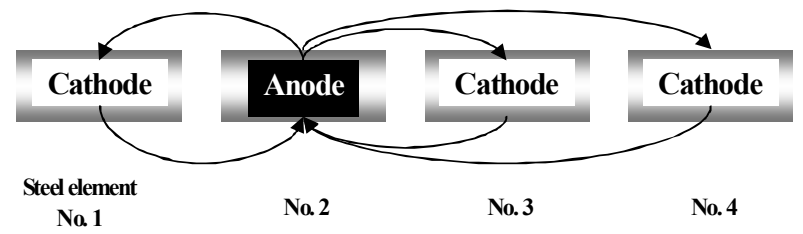

(1) Macrocell formation pattern.

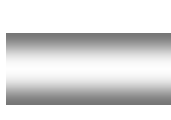

No. 1

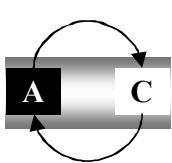

No. 2

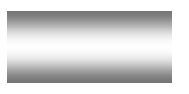

No. 3

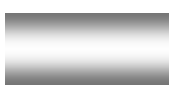

No. 4
(2) Microcell formation pattern.

Fig. 2 Corrosion cell formation pattern when steel element No. 2 is anode. 


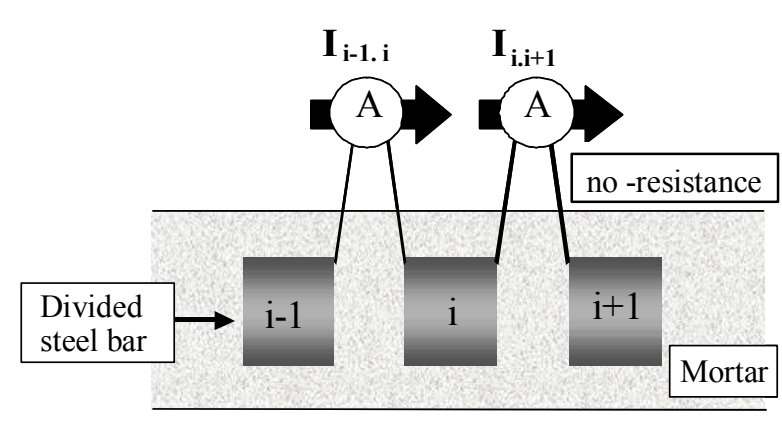

Fig. 3 Measurement of macrocell corrosion current.

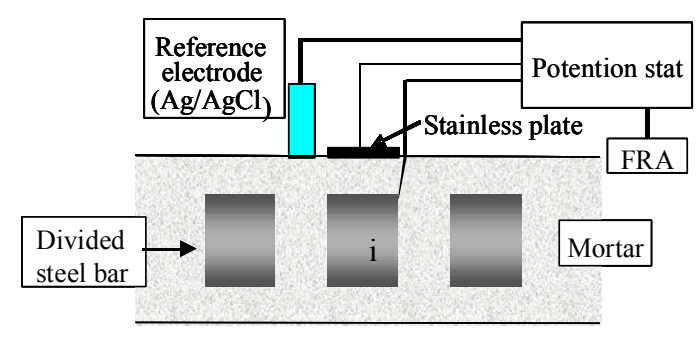

Fig. 4 Measurement of polarization resistance.

applied to the steel surface for 1 year, the corrosion rate of the steel is equivalent to $1.16 \mathrm{~mm} / \mathrm{year}$, as shown by Eq. (2).

$$
\begin{aligned}
& \frac{100 \times 10^{-6}\left(\mathrm{~A} / \mathrm{cm}^{2}\right)}{96400(\text { Coulomb })} \cdot \frac{55.85(\mathrm{~g} / \mathrm{mol})}{7.86\left(\mathrm{~g} / \mathrm{cm}^{3}\right) \cdot 2} \cdot 60(\mathrm{sec}) \\
& .60(\mathrm{~min}) \cdot 24(\text { hour }) \cdot 365(\text { day })=0.116(\mathrm{~cm} / \text { year }) \\
& =1.16(\mathrm{~mm} / \text { year })
\end{aligned}
$$

\section{2) Microcell corrosion current}

The microcell corrosion current density was obtained from measurements of the polarization resistance of a steel bar. Polarization resistance was measured by the AC impedance method with FRA (Frequency Response
Analyzer) with the lead wire between each divided steel bar cut as shown in Fig 4. For example, the microcell corrosion current density for steel element $i$ is given by Eq. (3).

$$
b_{i}=\frac{K}{R p_{i}}
$$

where $b_{i}=$ microcell corrosion current density of steel element $i\left(\mathrm{~A} / \mathrm{cm}^{2}\right), R p_{\mathrm{i}}=$ polarization resistance of steel component $\mathrm{i}\left(\mathrm{ohm} \cdot \mathrm{cm}^{2}\right)$, and $K=0.0209(\mathrm{~V})$, which is a constant per the reference used (Tsuru et al. 1979; Sanjuan et al. 1997).

The polarization resistance is the electrical resistance of the passivity film on the steel bar surface. Damage to the passivity film occurs through chloride ion attack, and the degree of damage does not change significantly in a short time. Therefore, it was judged that the microcell corrosion current could be the same as that in the exposure condition provided that the polarization resistance is measured within one hour after the lead wire between the steel elements is cut.

\section{3) Observation of steel bars}

After the test period, all specimens were broken for visual observation of the location of corrosion of the steel bars.

\section{Evaluation procedure}

\subsection{Determination of total corrosion electricity}

In order to determine the total corrosion electricity that was put into the steel bars, the areas under the macrocell anode current versus the time graphs for the whole 56 days (A1) and the microcell anode current versus the time graphs for the whole 56 days (A2) were computed and added as shown in Fig. 5.
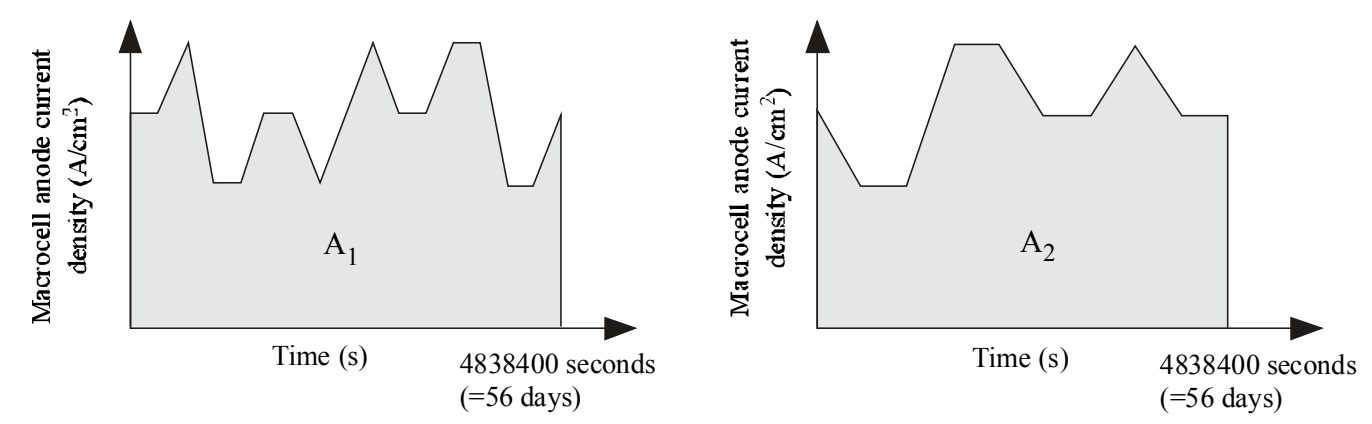

$$
\begin{aligned}
& \text { Total corrosion electricity }\left(\text { Coulomb } / \mathrm{cm}^{2}\right)=A_{1}+A_{2} \\
& A_{1}=\int_{0}^{4838400} \text { Macrocell anode current density }\left(A / \mathrm{cm}^{2}\right) d t \\
& A_{2}=\int_{0}^{4838400} \text { Microcell anode current density }\left(A / \mathrm{cm}^{2}\right) d t
\end{aligned}
$$$$
[\text { Coulomb }]=\int[A] d t
$$

Fig. 5 Definition of total corrosion electricity. 


\subsection{Evaluation of corrosion cell formation pat- tern}

The corrosion locations were judged by visual observation of the steel bars and the position at which the total corrosion electricity measured in the specimen was largest. To distinguish between macrocell and microcell prominent corrosions, the maximum values of the measured macrocell and microcell corrosion electricity were compared. If the maximum macrocell corrosion electricity was clearly larger than the maximum microcell corrosion electricity, when the former was 1.5 times larger than the latter, the corrosion type was designated as "macrocell prominent corrosion." On the other hand, if the microcell corrosion electricity was 1.5 times larger than the maximum macrocell corrosion electricity, it was judged as "microcell prominent corrosion." Further, when the quotient of the maximum corrosion electricity of the macrocell and microcell was larger than 0.66 $(2 / 3)$ smaller than $1.5(3 / 2)$, it was judged as "macrocell and microcell coexistence corrosion."

\subsection{Evaluation of corrosion rate}

The corrosion rate was calculated from the total corrosion electricity.

Normally, the corrosion rate would be evaluated as high if the corrosion current were higher than 10 micro $\mathrm{A} / \mathrm{cm}^{2}$. On the other hand, the corrosion rate would be evaluated as low if the corrosion current were lower than 1 micro $\mathrm{A} / \mathrm{cm}^{2}$. However, because deterioration was induced in specimens with a small cover thickness in this paper, the corrosion rate would be judged to be high in all cases if the above values were adopted. Therefore, the following criterion values were set up for the purpose of relative comparison in this experiment.

When the maximum corrosion electricity was below 20 Coulomb $/ \mathrm{cm}^{2}$ within 56 days (equivalent to

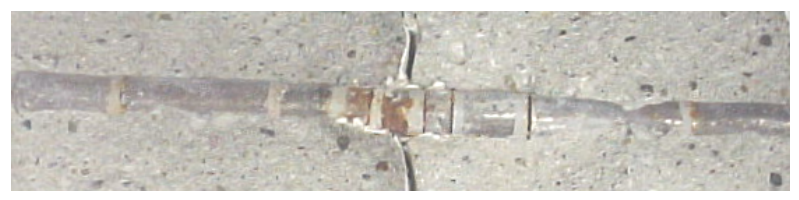

Fig. 6 Corroded steel at joint and its surroundings.

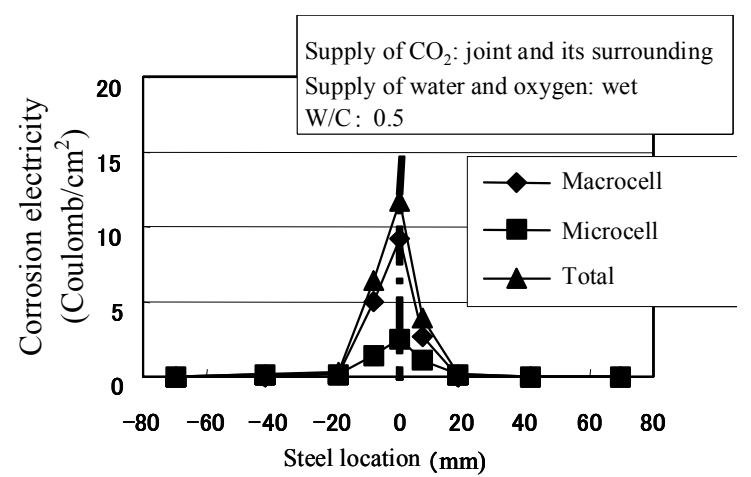

Fig. 7 Example of corrosion electricity distribution.
$0.05 \mathrm{~mm} /$ year), the corrosion rate was judged to be "low." When the maximum corrosion electricity exceeded 50 Coulomb $/ \mathrm{cm}^{2}$ in 56 days (equivalent to 0.12 $\mathrm{mm} /$ year), the corrosion rate was considered "high." This evaluation method was based on a reference (Miyagawa 1998) wherein the authors predicted that when the corrosion electricity was 20 Coulomb $/ \mathrm{cm}^{2}$ within 56 days, the yield stress of the steel bar would decline $70 \%$ after 30 years, compared to a new steel bar. On the other hand, in the case of 50 Coulomb $/ \mathrm{cm}^{2}$, the yield stress of the steel bar may decline $35 \%$ after 30 years.

\subsection{Example of evaluation}

Figure 6 shows corrosion of a steel element across the joint and its surroundings, in an area only $15 \mathrm{~mm}$ from the defect. On the other hand, the far steel elements did not corrode and became cathodes. Therefore, it is thought that use of the divided steel bar method to measure the macrocell corrosion current in this experiment was proper, because the three steel elements embedded in the corroding area had the same short length. Figure 7 shows an example of corrosion electricity distribution. It can be seen in this figure that the maximum values of both macrocell and microcell corrosion electricity were located in the steel across the joint and its surroundings. The maximum microcell corrosion electricity was 2.5 Coulomb $/ \mathrm{cm}^{2}$ while the maximum macrocell electricity density was 9.3 Coulomb $/ \mathrm{cm}^{2}$. Therefore, in this case, it was evaluated that macrocell prominent corrosion was formed at the joint and its surroundings because the quotient of the maximum corrosion electricity of the macrocell and microcell was 3.7. Furthermore, because the maximum total electricity current density was $11.8 \mathrm{Coulomb} / \mathrm{cm}^{2}$, which was lower than the standard value of $20 \mathrm{Coulomb} / \mathrm{cm}^{2}$, the corrosion rate was judged low.

\section{Results for chloride induced corrosion}

\subsection{Pattern of corrosion cell formation}

The corrosion cell formation pattern and the corrosion location are shown in a matrix in Fig. 8. The horizontal direction represents the exposure environment, while the vertical direction represents the supply position of chloride ions. The corrosion locations are indicated by the ellipses.

First, the influence of the supply position of chloride ions on the corrosion cell formation pattern was investigated. When chloride ions were introduced in the joint and/or its surroundings, corrosion occurred at the joint and/or its surroundings. Therefore, it could be said that corrosion occurs where the supply of chloride ions is concentrated.

Next, the influence of the water-cement ratio on the corrosion cell formation pattern was investigated. When the water-cement ratio was $30 \%$, macrocell prominent corrosion prevailed. On the other hand, microcell prominent corrosion prevailed as the water-cement ratio 


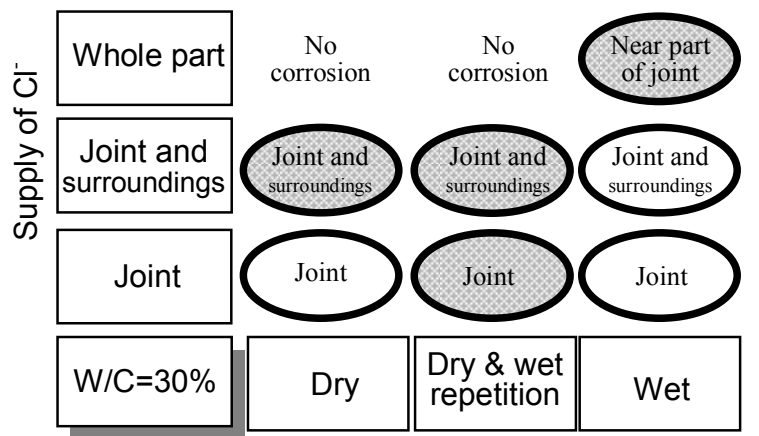

Environment

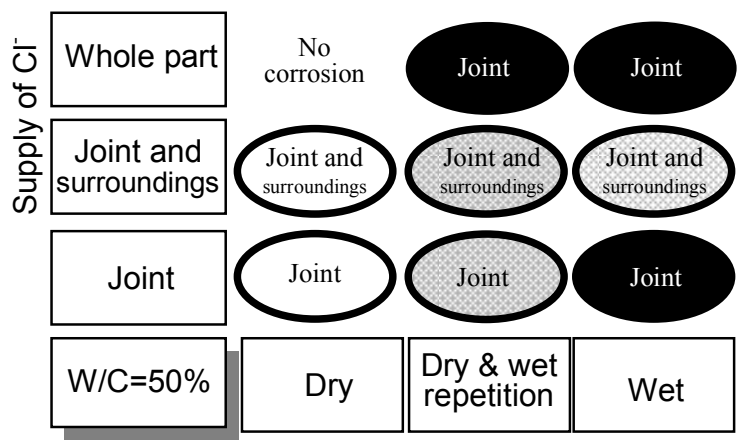

Environment

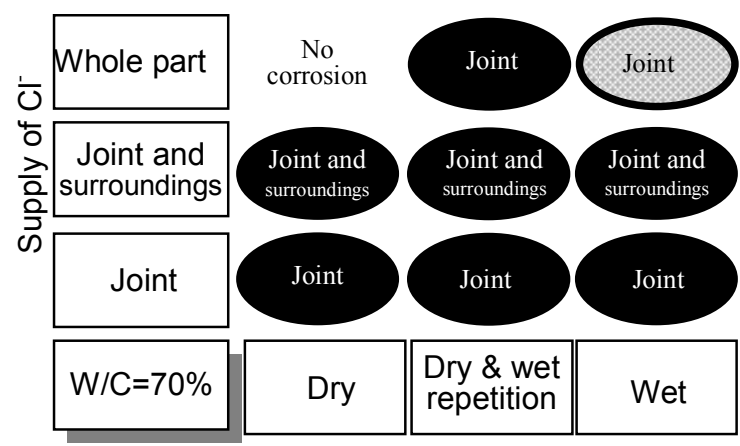

Environment

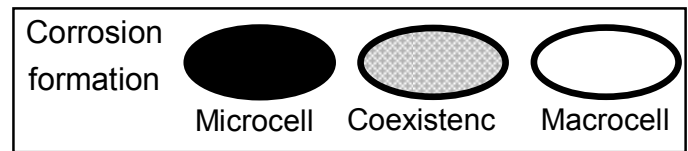

Fig. 8 Cell formation pattern and location of chloride induced corrosion.

increased. The reason is as follows. There is little permeation of chloride ions, oxygen and water in mortar with a low water-cement ratio. However, these substances can easily penetrate at or near the joint. Therefore, there was a big difference in the flux of these substances between the mortar and the joint. This made it easier for a macrocell to be formed than a microcell. On the other hand, when the water-cement ratio was high, there was greater permeation of these substances not only at the joint but also in the mortar, which facilitated microcell formation.

\subsection{Corrosion rate}

The corrosion rates for all the cases are shown in Fig. 9.

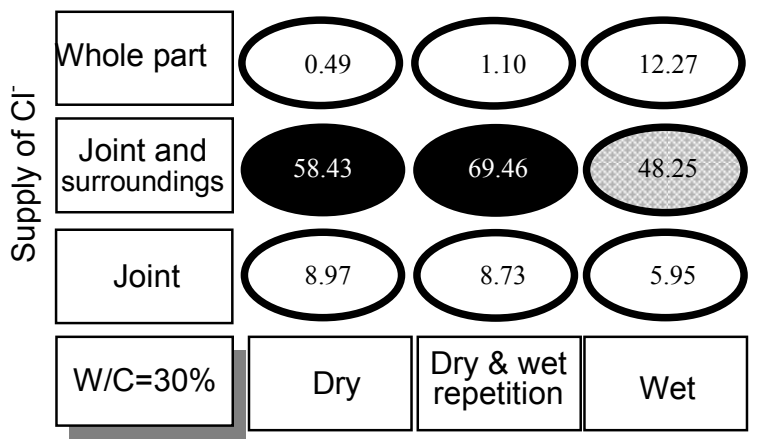

Environment

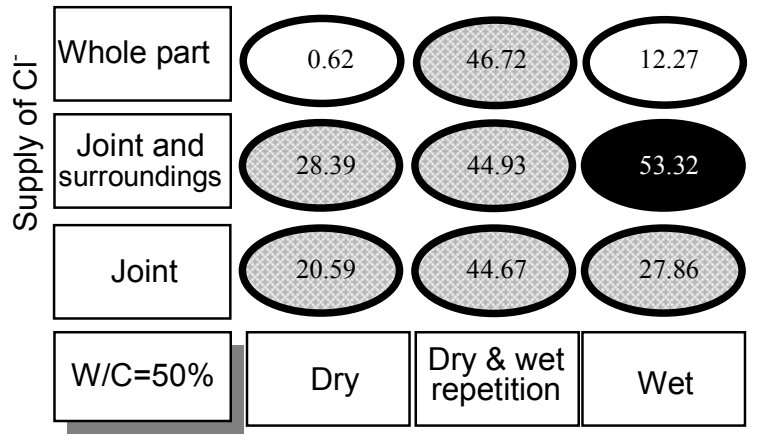

Environment

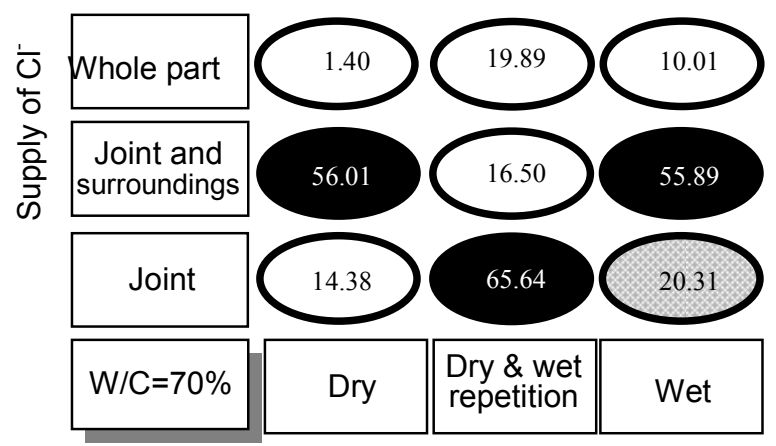

Environment

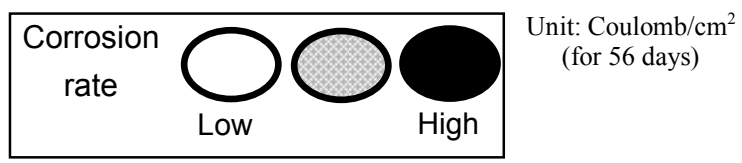

Fig. 9 Corrosion rate of chloride induced corrosion.

Both the horizontal and vertical axes in this figure correspond to those in Fig. 8.

Figure 9 shows that in general decreasing the water-cement ratio decreased the corrosion rate. However, when chloride ions were introduced at the joint and its surroundings, the corrosion rate became higher at the water-cement ratio of 0.3 compared to of the water-cement ratios of 0.5 and 0.7 . The reason seems to be that the lower the water-cement ratio, the larger the amounts of chloride ions, oxygen and water that are supplied to the joint and its surroundings due to differences in permeability. These amounts might reach a critical level causing corrosion to occur. As a result, the local corrosion rates would be high. 


\subsection{Summary}

The formation patterns and rate of the corrosion induced by chloride can be summed up as follows.

1) The macrocell pattern came into prominence in the case of a low water-cement ratio. On the other hand the microcell pattern became prominent as the water-cement ratio increased.

2) When a macrocell was prominently formed, the corrosion rate was high for the water-cement ratio of 0.3 compared with 0.5 or 0.7 .

\section{Result in carbonation induced corrosion}

\subsection{Pattern of corrosion cell formation}

The corrosion cell formation pattern and the corrosion locations are shown in matrices in Fig. 10. The horizontal axis and the ellipses have the same meanings as in Fig. 8. The vertical axis represents the supply position of carbon dioxide.

First, the influence of the supply position of carbon dioxide on the corrosion cell formation pattern was investigated. When the carbon dioxide penetrated the joint and/or its surroundings, corrosion occurred at the joint and/or its surroundings, like in the case of chloride induced corrosion. When carbon dioxide was applied to the whole specimen with the water-cement ratio of 0.7 , the corrosion location varied too. The reason was similar to the case of chloride induced corrosion. However, when carbon dioxide permeated only the joint in the case of the water-cement ratio of 0.3 , and the external environment was either dry or wet, the steel did not suffer corrosion. When carbon dioxide permeated the joint, the passive film at the joint was destroyed and it became an anode. However, mass permeability decreased in the mortar with a low water-cement ratio in the same manner as that dry specimens supplied less water and wet specimens supplied less oxygen gas. Therefore, the progress of corrosion seemed difficult. It was also thought that the steel was not corroded because water and oxygen were not supplied in sufficient amounts when carbon dioxide was applied to the whole specimen and the water-cement ratios were 0.3 and 0.5 .

Next, the influence of the water-cement ratio on the corrosion cell formation pattern was investigated. Macrocell prominent corrosion prevailed regardless of the water-cement ratio.

The carbonated mortar had fewer pores, as shown in Table 5. Therefore, the permeability into mortar became low because the carbonation progressed other than at the joint. As a result, there was a big difference in the flux of oxygen and water between the mortar and the joint.

Table 6 shows the ratio of oxygen flux to the steel located across the joint and the mortar with chloride ions or carbonation. The oxygen flux measurement method is shown in Fig. 11. The potentiostat was connected between a steel element and a stainless plate. The steel was made to be a negative electrode, and the stainless plate was made to be an anode. Then, a 860
$\mathrm{mV}$ potential difference was established, according to existing literature (Kiuchi 1983). The cathodic polarization curve in a similar specimen was measured beforehand, and it was confirmed to be the potential as a limiting current density. An example of the measured ca-
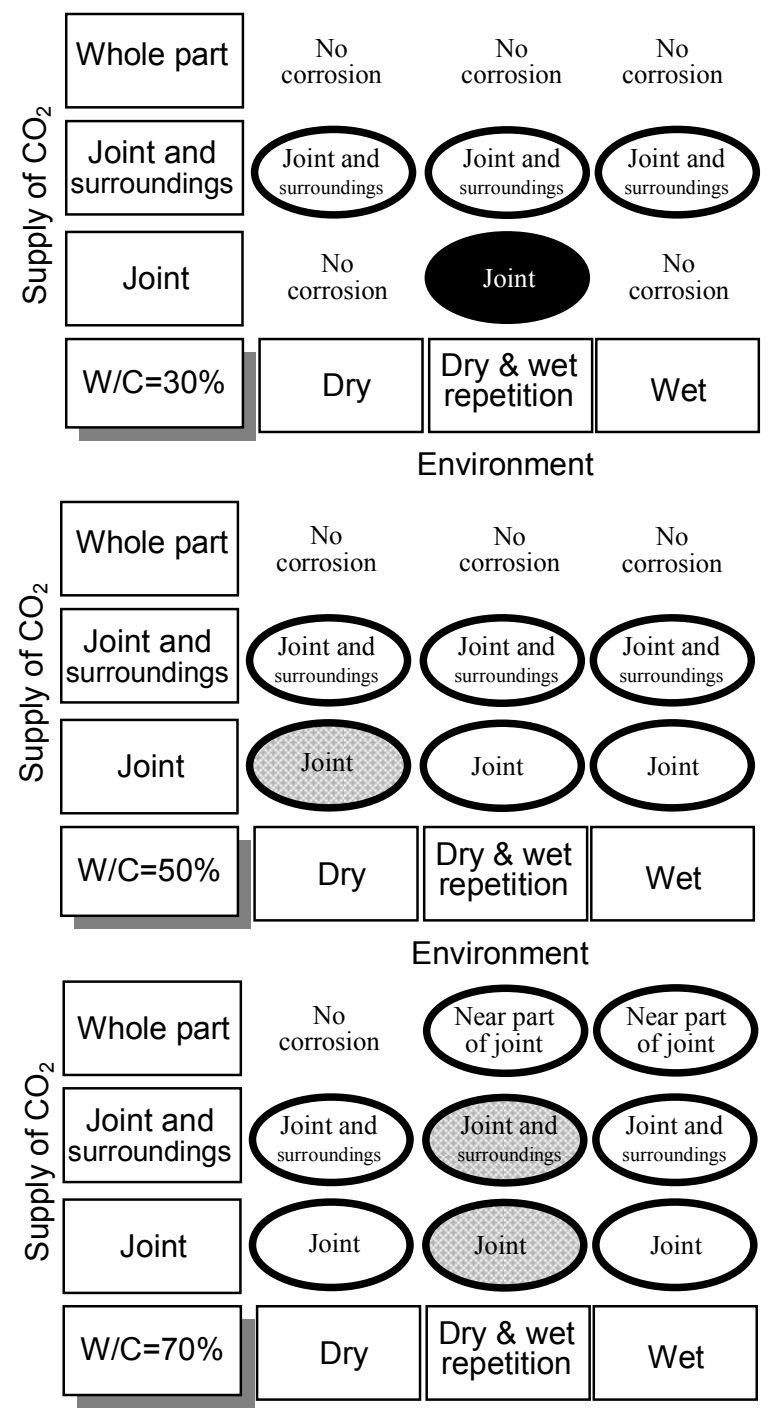

Environment

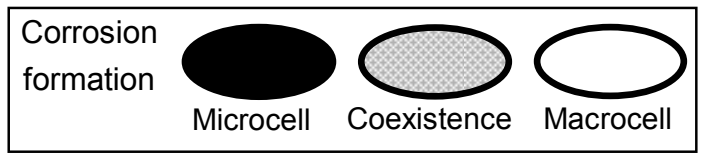

Fig. 10 Cell formation pattern and location of carbonation induced corrosion.

Table 5 Total pore volume of mortar with $50 \%$ of water-cement rate after curing.

\begin{tabular}{|c|c|c|c|}
\hline Chloride & Without & With & Without \\
\hline Carbonation & Without & Without & With \\
\hline $\begin{array}{c}\text { Total pore } \\
\left(* 10^{-2} \mathrm{cc} / \mathrm{g}\right)\end{array}$ & 9.25 & 9.38 & 3.25 \\
\hline
\end{tabular}




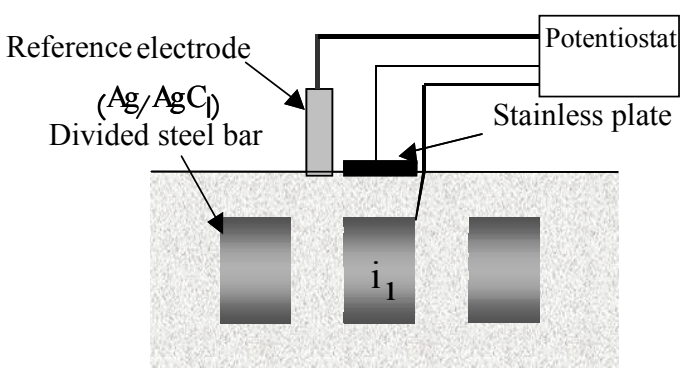

Fig. 11 Measurement method of apparent oxygen flux.

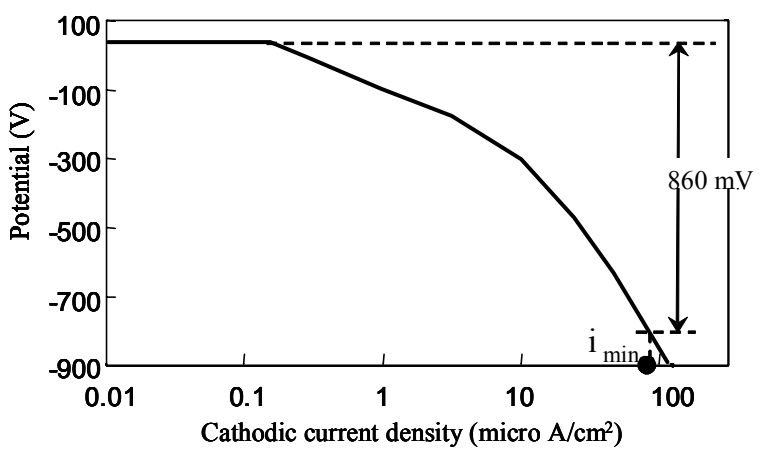

Fig. 12 Example of measured cathodic polarization.

thodic polarization curve is shown in Fig. 12. Then, the current in the steady state was measured, and the apparent oxygen flux passing inside the mortar and consumed in the cathodic reaction at the reinforcement surface was calculated from Eq. (4).

$$
\frac{d Q}{d t}=-\frac{i_{\lim }}{n \cdot F}
$$

where $\mathrm{d} Q / \mathrm{d} t=$ apparent oxygen flux for a steel element per unit time and area $\left(\mathrm{mol} / \mathrm{cm}^{2} \mathrm{sec}\right), i_{\text {lim }}=$ limit current density $\left(\mathrm{A} / \mathrm{cm}^{2}\right), n=$ electron count that reacts with oxygen molecule of $1 \mathrm{~mol}$ in cathodic reaction $(=4)$, and $F=$ Faraday constant $(=96500 \mathrm{Coulomb} / \mathrm{mol})$.

It was evident that the flux of oxygen intrusion across the joint became larger than that in mortar as this ratio increased. The results presented in Table 6 also confirmed that the ratio of the apparent flux of oxygen to the steel located across the joint and that of the mortar area increased more in specimens subjected to carbona-

Table 6 Ratio of apparent oxygen fluxes at steel across the joint to that at mortar.

\begin{tabular}{|c|c|c|c|c|c|c|c|}
\hline Chloride & Without & \multicolumn{3}{|c|}{ With } & \multicolumn{3}{c|}{ Without } \\
\hline Carbonation & Without & \multicolumn{3}{|c|}{ Without } & \multicolumn{3}{c|}{ With } \\
\hline W/C & 0.5 & 0.3 & 0.5 & 0.7 & 0.3 & 0.5 & 0.7 \\
\hline $\begin{array}{c}\text { Ratio of } \\
\text { oxygen flux } \\
\text { at the joint } \\
\text { to that at } \\
\text { mortar }\end{array}$ & 4.59 & 5.86 & 3.28 & 2.59 & 65.56 & 23.57 & 5.94 \\
\hline
\end{tabular}

tion compared to specimens subjected to chloride ions. The large difference in the apparent flux of oxygen and water between the mortar and the joint promoted macrocell formation.

Additionally, alkalinity may decrease in the defect locations. Therefore, the difference in $\mathrm{pH}$ between the mortar and the joint is conducive to macrocell formation.

\subsection{Corrosion rate}

The corrosion rates for all cases are shown in Fig. 13. It is seen that, in general, decreasing the water-cement ratio could decrease the corrosion rate. The reason for this was that the apparent flux of oxygen permeated in mortar decreased while the water-cement ratio decreased. Additionally, the reason was that the electrical resistivity of mortar increased while the water-cement ratio decreased.

\subsection{Summary}

The formation patterns and rate of the corrosion induced by carbonation can be summed up as follows.

1) Macrocell came into prominence regardless of the water-cement ratio.

2) Decreasing the water-cement ratio can decrease the corrosion rate.

\section{Comparison between corrosions induced by chloride and carbonation}

\subsection{Corrosion cell formation pattern}

As a result of judging the corrosion position, it was confirmed that the penetration location corroded when the corrosive agent permeated a defect or the vicinity regardless of whether corrosion was by chloride or carbonation. On the other hand, as a result of distinguishing between macrocell prevalent corrosion and microcell prevalent corrosion, the corrosion cell formation pattern was found to differ between corrosion by chloride and corrosion by carbonation. That is, in the case of chloride induced corrosion, macrocell prominent corrosion prevailed in the case of the low water-cement ratio. However, as the water-cement ratio increased, microcell prominent corrosion prevailed. In contrast, macrocell prominent corrosion prevailed regardless of the water-cement ratio in carbonation induced corrosion.

The corrosion cell formation pattern for chloride induced corrosion can be explained by the difference in the flux of oxygen and water between the mortar and the joint, as described in the preceding chapters. In the case of chloride induced corrosion, the flux of substances penetrating the steel in the mortar part decreased the lower the water-cement ratio. On the other hand, the penetration of these substances was facilitated in the case of high water-cement ratios. Therefore, decreasing the water-cement ratio produced a bigger difference in the flux of oxygen and water between the mortar and the joint. On the other hand, increasing the water-cement 
ratio resulted in a smaller difference in the flux of oxygen and water between the mortar and the joint. As a result, macrocell prominent corrosion prevailed in the low water-cement ratio while microcell prominent corrosion prevailed in the high water-cement ratio.

In the case of carbonation induced corrosion, the pore volume of mortar decreased due to carbonation. The

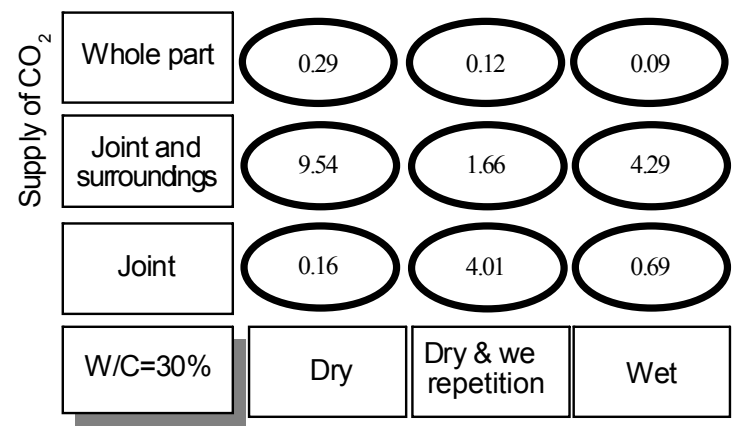

Environment

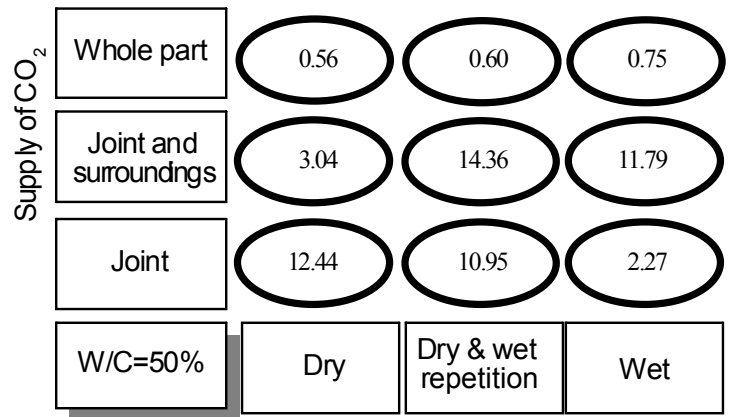

Environment

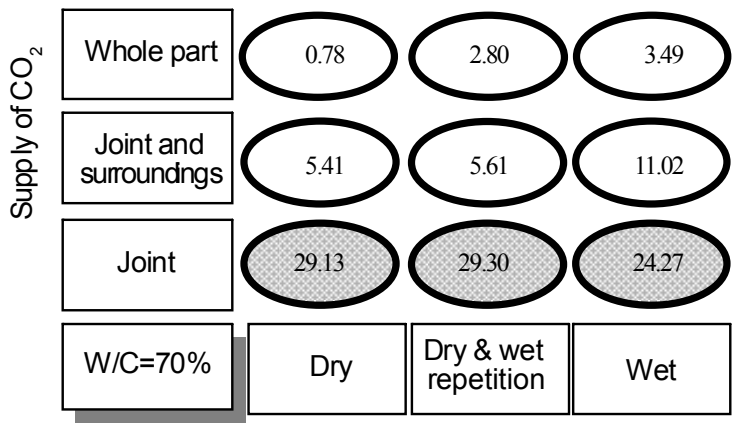

Environment

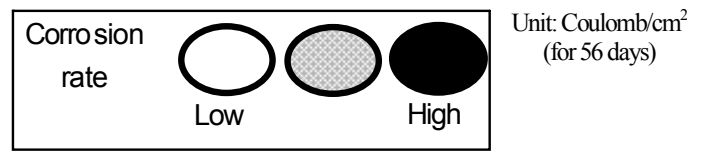

Fig. 13 Corrosion rate of carbonation induced corrosion.

Table 7 Comparison between rates of corrosions induced chloride and carbonation.

\begin{tabular}{|c|c|c|c|}
\hline & Low & Normal & High \\
\hline Chloride & 13 & 8 & 6 \\
\hline Carbonation & 25 & 2 & 0 \\
\hline
\end{tabular}

flux of substances penetrating the steel in mortar decreased, resulting in a big difference in the flux of oxygen and water between the mortar and the joint. Hence, the carbonation induced corrosion produced primarily macrocell prominent corrosion.

\subsection{Corrosion rate}

The rates of corrosion induced by chloride and carbonation are compared using Figs. 9 and 13. Table 7 compares the rates of corrosion based on Figs. 9 and 13. According to this table, the rate of chloride induced corrosion is higher than that of carbonation induced corrosion.

An experiment was conducted to examine the influence of chloride ions and $\mathrm{pH}$ on the polarization characteristic of steel. A lead wire with a $1 \mathrm{~cm}$ in length was soldered to the edge of a steel element and the juncture was covered with epoxy resin. Three steel elements were soaked in each $\mathrm{Ca}(\mathrm{OH})_{2}$ aqueous solution with a $\mathrm{pH}$ value of $12.4,10.5$ and 8.5. Simultaneously, the other three steel elements were also soaked in the $\mathrm{Ca}(\mathrm{OH})_{2}$ aqueous solutions each with an additional $\mathrm{NaCl}$ of $3.1 \mathrm{wt} \%$.After soaking for 28 days, the anodic polarization curve of the steel elements was drawn, as shown in Fig. 14. According to this figure, the rate of corrosion increased as the $\mathrm{pH}$ decreased in the presence of chloride ions. The case of $12.4 \mathrm{pH}$ with chloride ions and the case of $10.5 \mathrm{pH}$ or $8.5 \mathrm{pH}$ without chloride ions were compared. The graph indicated that the anodic current of the former was larger. Based on this result, the environment of the steel in concrete affected by chloride ions and carbonation could also be compared. One environment involved concrete influenced by chloride ions when $\mathrm{pH}$ was 12.4 . The other environment involved concrete influenced by carbonation of $\mathrm{pH} 10.5$ or $\mathrm{pH} 8.5$ without chloride ions. It was quite evident that the corrosion environment developed in concrete influenced by chloride ions was worse than that in concrete influenced by carbonation. For this reason, the rate of the chloride induced corrosion might be higher than the rate of carbonation induced corrosion.

The permeability decreased because the pore volume

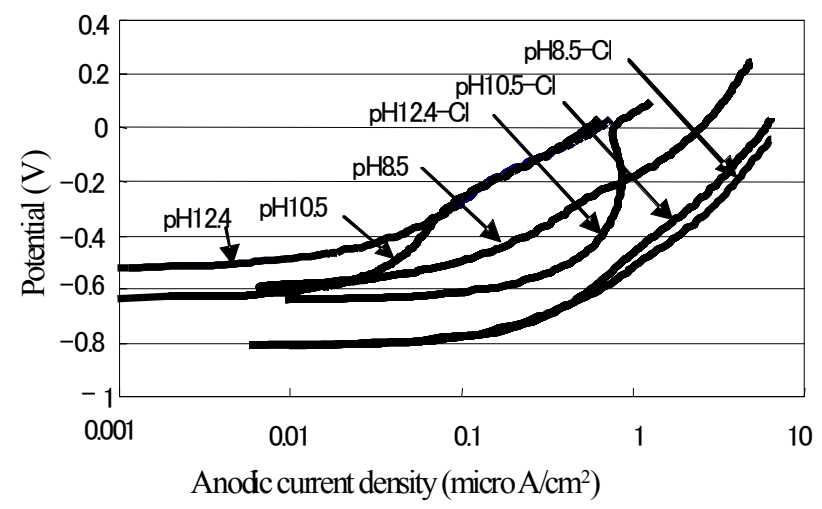

Fig. 14 Influence of chloride ions and $\mathrm{pH}$ on polarization characteristic of steel. 
of the mortar decreased when it was influenced by carbonation, as shown in Table 5. Therefore, in the case of the steel in mortar influenced by carbonation, a cathode reaction was suppressed and the corrosion rate was decreased. This was another reason why the rate of carbonation induced corrosion was lower compared to the rate of chloride induced corrosion.

\section{Conclusions}

In this study, the corrosion cell formation pattern and the rate of corrosion by chloride and carbonation in mortar with defects were investigated, tabulated and compared. The conclusions are as follows.

1) The corrosion cell formation patterns and corrosion rates of all 54 cases were comprehensively tabulated and compared. The parameters were the supply position of chloride ions or carbon dioxide, the environmental condition, and the water-cement ratio of mortar.

2) For chloride induced corrosion, decreasing the water-cement ratio (0.3) will increase the activity of macrocell prominent corrosion. On the other hand, increasing the water-cement ratio $(0.7)$ will increase the activity of microcell prominent corrosion. Also, a lower water-cement ratio does not necessarily guarantee a lower corrosion rate. For example, based on our experience, if chloride ions were supplied at the joint and its surroundings when the environment was the dry or repeated wet/dry condition, specimens with the water-cement ratio of 0.3 had a corrosion rate of $0.17 \mathrm{~mm} /$ year at the defect. On the other hand, in the case of the water-cement ratio of 0.7 , the corrosion rate was $0.04 \mathrm{~mm} /$ year.

3) For carbonation induced corrosion, macrocell prominent corrosion prevailed regardless of the water-cement ratio. Also, a lower water-cement ratio guarantees a lower corrosion rate.

4) For both chloride induced corrosion and carbonation induced corrosion, corrosion occurred where the corrosive substances heavily penetrated at the defect.

5) The rate of corrosion induced by chloride was found to be higher than that by carbonation.

6) Based on the comparison of the pattern of corrosion cell formation, it was shown that macrocell prominent corrosion prevailed when there was a big difference in the flux of corrosive substances between the mortar and the joint. In contrast, microcell prominent corrosion prevailed when the difference in the flux of these substances between the mortar and the joint decreased.

Based on the above results, it became clear that the macrocell pattern prevailed and the corrosion rate increased when the water-cement ratio was low and when there was a defect in a chloride ion attack condition. Our conclusion is that serious maintenance is necessary when there are defects and the reinforcement supplied contains chloride ions, even when the water-cement ratio is low.

\section{Acknowledgements}

The authors are grateful to Mr. Hayato Kimura, who verified some of the tests described in Chapters 4 and 5, and Prof. Toru Tsuru, who provided advice regarding the discussion in Chapter 6.

\section{References}

Andrade, C., Maribona, I. R., Feliu, S., Gonázlez, J. A. and Feliu, Jr., S. (1992). "The effect of macrocells between active and passive areas of steel reinforcements." Corrosion science, 33(2), 237-249.

Beeby, A. W. (1983). "Cracking, cover, and corrosion of reinforcement." Concrete International, 5(2), 35-40.

Kamiyama, H. (1972). "Cracks in concrete and corrosion of steel bars." JCA Proceedings of Cement \& Concrete, 491-493. (in Japanese)

Kiuchi, Y., Miyagawa, T. and Okada, K. (1983). "Electric resistance and oxygen permeation of the concrete." Annual Report of Japan Society of Civil Engineers, 38(5), 265-266. (in Japanese)

Miyagawa, T., Takewaka, K., Demura, K., Masuda, Y. and Moriwake, A. (1998). "Technical committee report on the rehabilitation of concrete structures." Proceedings of the Japan Concrete Institute, 20(1), 39-48. (in Japanese)

Ominda, N. and Kato, Y. (2009). "Macro-cell corrosion in reinforcement of concrete under non-homogeneous chloride environment." Journal of Advanced Concrete Technology, 7(1), 31-40.

Otsuki, N., Marish, S. Madlangbayan, Nishida, T., Saito, T. and Baccay, M. A. (2009). "Temperature dependency of chloride induced corrosion in concrete." Journal of Advanced Concrete Technology, 7(2), 41-50.

Sanjuan, M. A., Andrade, C. and Bentur, A. (1997). "Effect of crack control in mortars containing polypropylene fibers on the corrosion of steel in a cementitious matrix." ACI Materials Journal, 94(2), 134-141.

Schiebl, P. and Raupach, M. (1997). "Laboratory studies and calculations on influence of crack width on chloride induced corrosion of steel in concrete." $A C I$ Materials Journal, 94(1), 56-62.

Tsuru, T., Maeda, R. and Haruyama, S. (1979). "Application of A-C corrosion monitor to localized corrosion.” Corrosion Engineering, 28(12), 638-644. (in Japanese) 